\begin{tabular}{c}
\hline OPEN \\
JOURNAL \\
SYSTEMS \\
\hline \hline
\end{tabular}

ISSN:2237-2202
Available on line at Directory of Open Access Journals

Journal of Hyperspectral Remote Sensing v.8, n.2 (2018) 47-59

www.periodicos.ufpe.br/revistas/jhrs
Journal of

Hyperspectral

Remote Sensing

\title{
Application of Advanced Spaceborne Thermal Emission and Reflection Radiometer (ASTER) multispectral imagery to mineral and lithologic mapping in southern West Greenland
}

\author{
Enton Bedini* \\ *Geological Survey of Denmark and Greenland (GEUS), Øster Voldgade 10, 1350 Copenhagen K, Denmark \\ Email: enton_bedini@hotmail.com com (Corresponding author).
}

Received 6 August 2018, accepted 28 September 2018

\begin{abstract}
Remote sensing data acquired by the Advanced Spaceborne Thermal Emission and Reflection Radiometer (ASTER) were used for mineral and lithologic mapping at the Sarfartoq carbonatite complex area in southern West Greenland. The geology of the study area consists of carbonatites, fenites, hydrothermal alteration zones, gneisses, alluvial deposits etc. The Adaptive Coherence Estimator algorithm was used to analyze the remote sensing data. The reference spectra were selected from the imagery. The mapping results show the distribution of carbonatite, hydrothermally altered zones, fenite, and sericite. In addition, lichen and tundra green vegetation were also mapped. Due to the moderate spatial resolution of ASTER SWIR bands, it was not possible to detect and map the rock units in some parts of the study area. The study shows the possibilities and limitations of the use of the ASTER multispectral imagery for geological studies in the Arctic regions of West Greenland. The paper is the first reported study on the use of ASTER data for mineral and lithologic mapping in the Arctic regions of West Greenland.

Keywords: remote sensing, ASTER, mineral, carbonatite, Greenland
\end{abstract}

\section{Introduction}

The remote sensing technology can assist the ever increasing geological mapping and exploration activities in Greenland (Tukiainen and Thorning, 2005; Tukiainen and Thomassen, 2010; Bedini, 2012, 2017; Rasmussen et al., 2013; Bedini and Rasmussen, 2018; Sørensen and Guarnieri, 2018;). Especially, the analysis of widely-available satellite remote sensing imagery is important for reconnaissance mapping and detection of outcropping lithologies and hydrothermal alteration (Conradsen and Harpøth, 1984; Bedini, 2011), in the first stages of a geological project.

The Sarfartoq carbonatite complex is part of an alkaline suite of igneous rocks that occurs in the Archean basement of southern West Greenland (Secher et al., 2009). The Sarfartoq carbonatite complex consists of various lithologies, and hydrothermal alteration zones that contain mineralization of rare earth elements (Secher, 1986). The Arctic regions of southern West Greenland are characterized by abundant tundra green vegetation and lichen cover of the rock substrate that represent a challenge for the use of the remote sensing data to detect and map the surface mineralogy and lithology (Rivard and Arvidson, 1992). Limited research has been carried out on the evaluation of satellite multispectral remote sensing data for geological mapping and exploration in southern West Greenland.

The Advanced Spaceborne Thermal Emission and Reflection Radiometer (ASTER), developed by the Ministry of International Trade and Industry (METI), Japan, has been operated aboard the U.S. National Aeronautics and Space Administration (NASA) Earth Observation System (EOS) Terra platform since 2000 (Yamaguchi et al., 1998; Abrams, 2015; Obata et al., 2015). The ASTER measures reflected solar radiation in three bands between 0.52$0.86 \mu \mathrm{m}$ in the visible to near infrared (VNIR) wavelength region, and in six bands from $1.6 \mu \mathrm{m}$ to $2.43 \mu \mathrm{m}$ in the short-wave infrared (SWIR) wavelength region (Table 1). The spatial resolution is $15 \mathrm{~m}$ for the VNIR bands, and $30 \mathrm{~m}$ for the SWIR bands (Table 1). Emitted radiation is measured at 90 $\mathrm{m}$ spatial resolution in five bands in the $8.12 \mu \mathrm{m}$ to $11.65 \mu \mathrm{m}$ thermal infrared (TIR) wavelength region (Yamaguchi et al., 1998; Abrams, 2015). 
Table 1 - Performance parameters for the ASTER radiometer (after Yamaguchi et al. 2001)

\begin{tabular}{|c|c|c|c|c|}
\hline Spectrometer & $\begin{array}{l}\text { Band } \\
\text { number }\end{array}$ & $\begin{array}{l}\text { Bandpass (spectral } \\
\text { range) }(\mu \mathrm{m})\end{array}$ & $\begin{array}{l}\text { Spatial } \\
\text { resolution }\end{array}$ & $\begin{array}{l}\text { Signal } \\
\text { quantization } \\
\text { levels }\end{array}$ \\
\hline \multirow[t]{4}{*}{ VNIR } & 1 & $0.52-0.60$ & $15 \mathrm{~m}$ & 8 bits \\
\hline & 2 & $0.63-0.69$ & $15 \mathrm{~m}$ & 8 bits \\
\hline & $3 \mathrm{~N}$ & $0.78-0.86$ & $15 \mathrm{~m}$ & 8 bits \\
\hline & $3 B$ & $0.78-0.86$ & $15 \mathrm{~m}$ & 8 bits \\
\hline \multirow[t]{6}{*}{ SWIR } & 4 & $1.600-1.700$ & $30 \mathrm{~m}$ & 8 bits \\
\hline & 5 & $2.145-2.185$ & $30 \mathrm{~m}$ & 8 bits \\
\hline & 6 & $2.185-2.225$ & $30 \mathrm{~m}$ & 8 bits \\
\hline & 7 & $2.235-2.285$ & $30 \mathrm{~m}$ & 8 bits \\
\hline & 8 & $2.295-2.365$ & $30 \mathrm{~m}$ & 8 bits \\
\hline & 9 & $2.360-2.430$ & $30 \mathrm{~m}$ & 8 bits \\
\hline \multirow[t]{5}{*}{ TIR } & 10 & $8.125-8.475$ & $90 \mathrm{~m}$ & 12 bits \\
\hline & 11 & $8.475-8.825$ & $90 \mathrm{~m}$ & 12 bits \\
\hline & 12 & $8.925-9.275$ & $90 \mathrm{~m}$ & 12 bits \\
\hline & 13 & $10.25-10.95$ & $90 \mathrm{~m}$ & 12 bits \\
\hline & 14 & $10.95-11.65$ & $90 \mathrm{~m}$ & 12 bits \\
\hline \multicolumn{5}{|c|}{$\begin{array}{l}\text { Swath width: } 60 \mathrm{~km} \\
\text { Band to band registration: Intra-telescope: } 0.2 \text { pixels, inter-telescope: } 0.3 \text { pixels of } \\
\text { coarser band }\end{array}$} \\
\hline
\end{tabular}

The ASTER VNIR bands are useful for the detection and mapping of iron stained zones. The six ASTER SWIR bands record in a wavelength region where carbonate, hydrate and hydroxide mineral spectra display molecular absorption features related to overtones and combination tones (Hunt, 1982; Clark, 1999; Crosta et al., 2003; Rowan and Mars, 2003; Rowan et al., 2005; Di Tommaso and Rubinstein, 2007; Tangestani et al., 2008; Mars and Rowan, 2011; Pour and Hashim, 2012; Guha et al., 2013; Son et al., 2014; Tayebi et al., 2014; Rajendran and Nasir, 2015; Kumar et al., 2015; Pour et al., 2017). The ASTER TIR bands can detect and map the spatial distribution of minerals (e.g., quartz, carbonate), and lithologies that display emission features in the thermal infrared atmospheric window $(8-12 \mu \mathrm{m})$ (Rockwell and Hofstra, 2008; Ninomiya and Fu, 2016). However, the utility of ASTER TIR bands for district-level studies is hampered by the low $90 \mathrm{~m}$ spatial resolution.

The purpose of this paper is to report on the application of the ASTER data to retrieve information for the lithology and mineralogy of the Sarfartoq carbonatite complex in southern West Greenland. The objectives of the study were: (1) to provide an application of the ASTER data to the lithologic mapping of carbonatite complexes; (2) to assess the use of ASTER data for lithologic mapping and exploration in the Arctic regions of West Greenland. The paper is the first reported study on the use of
ASTER data for mineral and lithologic mapping in the Arctic regions of West Greenland.

\section{Materials and methods}

\section{Geology of the study area}

The Sarfartoq carbonatite complex is an intrusion in Archean and Proterozoic gneisses, in southern West Greenland (Figure 1; Secher and Larsen, 1980). The carbonatite complex is composed of a carbonatite core zone and a marginal zone of altered gneisses with carbonatite dykes (Figure 2). The rocks of the inner carbonatite core zone are mainly dolomite carbonatites. The outer carbonatite core zone consist of carbonatite dykes and fenitized country rocks (Figure 2, 3a-b). A fenite zone surrounds the carbonatite core zone. The marginal alteration zone consists of gneisses frequently altered due to hydrothermal activity (Secher and Larsen, 1980). Locally, occur 50-200 $\mathrm{m}$ wide shear zones (Figure 2, $3 \mathrm{c})$ that consist of strongly hematized gneisses with carbonatite dykes. In this shear zones occur anomalies of thorium (Druecker and Simpson, 2011), often associated with rare earth elements mineralization. A deposit of rare earth elements was recently discovered in the north-western margin of the carbonatite complex (Figure 2; Druecker and Simpson, 2011).

The best outcrop of the Sarfartoq carbonatite occurs in the cliffs north of the Paradise Valley (Figure 3a). Glacial and alluvial sediments of the valley floor cover most of the carbonatite core zone. The Arctic 
tundra green vegetation is abundant in the study area (Figures 3, 4). It is also to be noted a characteristic ubiquitous black lichen cover of the gneiss rocks
(Figure 3d). The fenites, probably due to their sodic chemical composition are associated with a particular orange-colour lichen (Figure 3b).

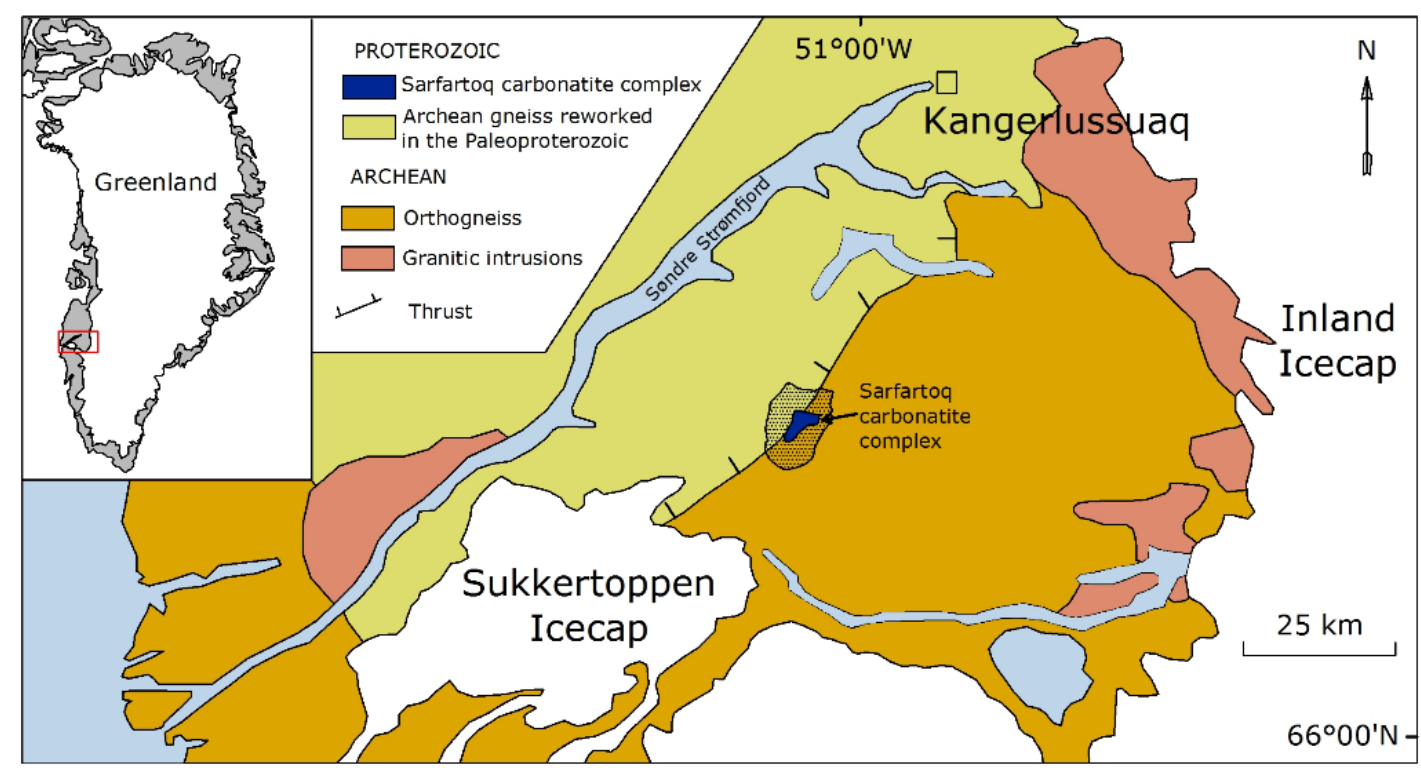

Figure 1 - Schematic map showing the geographic and geologic position of the Sarfartoq carbonatite in southern West Greenland (modified from Allaart, 1982).

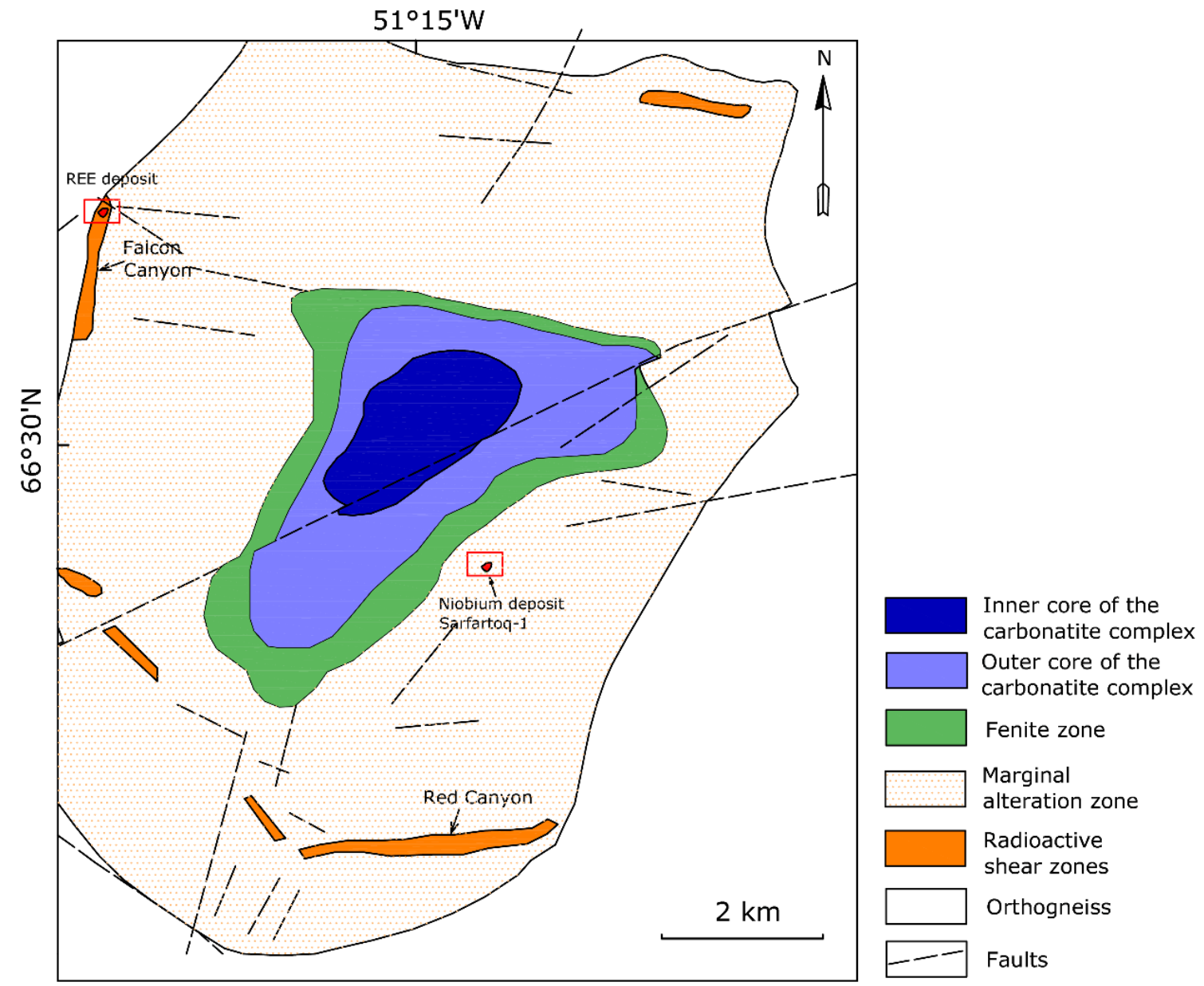

Figure 2 - Schematic geological map of the study area (modified from Secher 1986). 

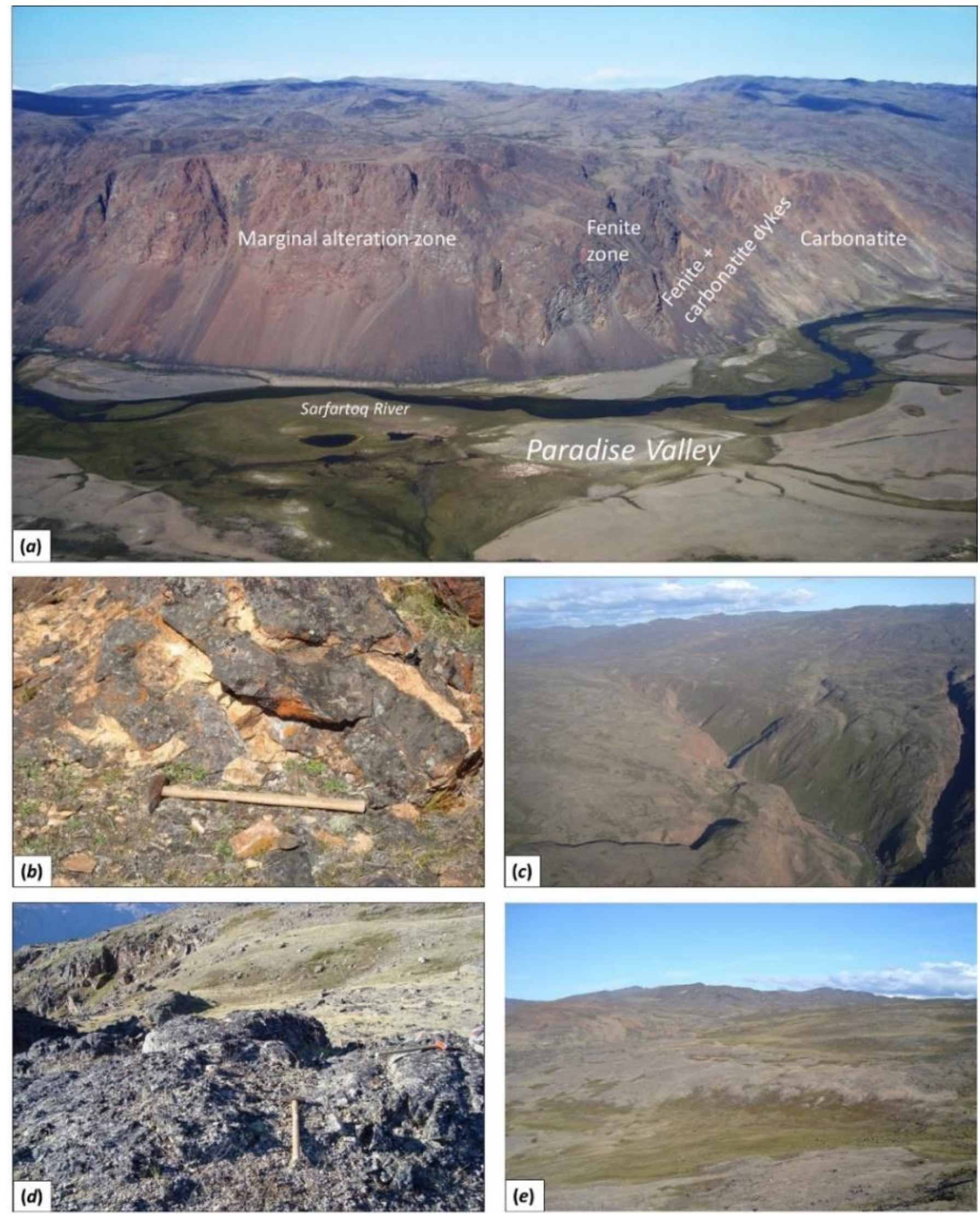

Figure 3 - (a) The outcropping carbonatite core zone, fenite zone, and marginal alteration zone of the Sarfartoq carbonatite complex, north of the Paradise Valley. The height of the cliffs above the valley plain level is ca. $500 \mathrm{~m}$. (b) Fenite rocks intersected by carbonatite dykes. (c) The Red Canyon, a shear zone in the southern margin of the carbonatite complex. (d) Granite gneisses with a dense black lichen cover. $(e)$ Typical environment in the plateau level. Photos by the author. 


\section{The ASTER data}

The Sarfartoq ASTER data analysed in this study, were recorded on August 5, 2003. The ASTER data of the Sarfartoq carbonatite complex area (Figure 4) were obtained partially corrected for atmospheric absorption features and scattering (ASTER standard product AST_07XT that includes the correction for the cross-talk effect) from the Earthdata of NASA's Earth Observing System Data and Information System (EOSDIS) (https://earthdata.nasa.gov/). The VNIR data were co-registered to the SWIR data by degrading the spatial resolution of the VNIR data to the $30-\mathrm{m}$ spatial resolution of the SWIR data.
Analytical Spectral Device (ASD) in situ spectral reflectance measurements of a site consisting of alluvial gravel deposits were used to find the necessary calibration coefficients to improve the correction to surface reflectance of the AST_07XT product (Mars and Rowan, 2011). The average of 20 ASD in situ reflectance spectra was resampled to the ASTER bandpasses. The resampled reflectance spectrum was divided by the average of several ASTER pixels over the same location to determine the calibration coefficients. The calibration coefficients were used to rescale the AST_07XT product (Mars and Rowan, 2011), resulting in an improved surface reflectance of the ASTER Sarfartoq scene.

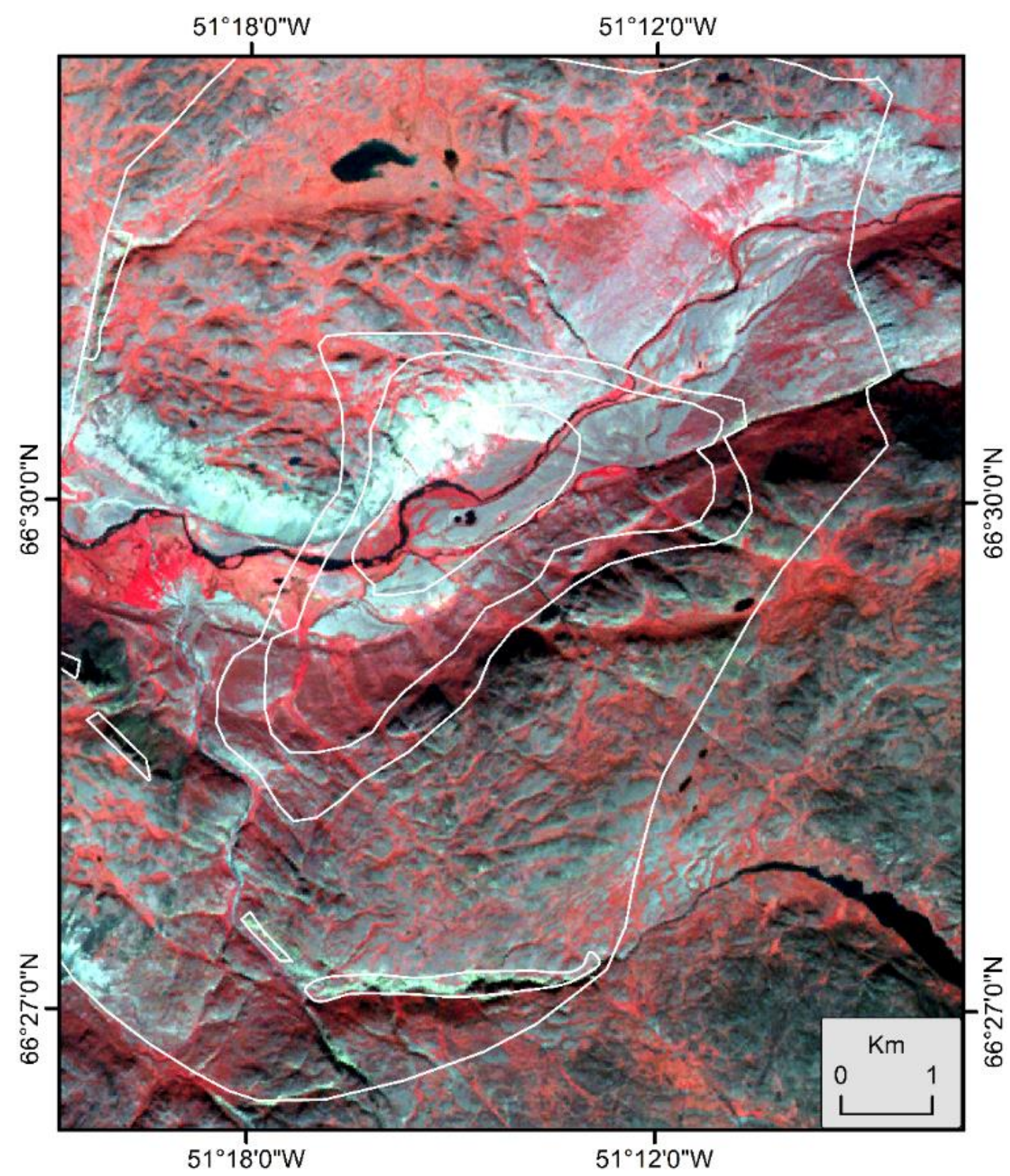

Figure 4 - Colour composite of the ASTER subset analysed in this study (ASTER bands 3, 2, and 1 as RGB). The boundaries of the schematic geological map of the Sarfartoq carbonatite (Figure 2) are shown on the image for reference. 


\section{The spectral reflectance classes}

The spectral reflectance properties of rocks and vegetation were recorded using an Analytical Spectral Device Spectrometer (ASD). The ASD has 2151 spectral channels in the 0.35- to $2.5 \mu \mathrm{m}$ wavelength region. Representative ASD reflectance spectra of the rock samples and vegetation in the Sarfartoq area are shown in figures 5 and 6 . In these figures are also plotted the same representative reflectance spectra resampled to the ASTER bandpasses.

The carbonatites are igneous rocks that contain more than 50\% carbonate minerals (Jones et al., 2013). The spectral reflectance of the carbonatite samples is dominated from the spectral reflectance of the carbonate minerals (dolomite, calcite) (Figure 5). The carbonate anion causes a series of absorptions in the SWIR region (Gaffey, 1986). In general, the absorption features in dolomite spectra occur at shorter wavelengths than the equivalent absorption features in calcite spectra (Gaffey, 1986). Absorption features due to ferric and ferrous iron occur at wavelengths shorter than $1.6 \mu \mathrm{m}$ (Figure 5). Resampled to the ASTER bandpasses the carbonatite spectrum retains the main carbonate absorption feature in the short wave infrared wavelength region centered at $2.33 \mu \mathrm{m}$ (ASTER band 8). The ferric iron charge transfer causes lower reflectance at ASTER band 1 as compared to ASTER bands 2 and 3. To be noted that the carbonatite spectrum also contains a broad ferrous iron $\left(\mathrm{Fe}^{2+}\right)$ absorption feature at 1-1.3 $\mu \mathrm{m}$ (Gaffey, 1986) that cannot be resolved by ASTER that has no spectral channels in this wavelength region.

Fenites are formed due to the metasomatism (fenitization) of the country rocks from alkaline fluids related to the carbonatite intrusion. Fenites contain aegirine, alkali amphibole and $\mathrm{K}$-feldspar (Winter, 2001). The fenite reflectance spectra display $\mathrm{Mg}-\mathrm{OH}$ features (due to amphibole) at $2.32 \mu \mathrm{m}$ and $2.38 \mu \mathrm{m}$ (Figure 5; Bedini and Tukiainen, 2009). The presence of sericite (due to weathering of K-feldspar) in fenites could be noted by a shallow $\mathrm{Al}-\mathrm{OH}$ feature near 2.20 $\mu \mathrm{m}$. The fenite spectrum (Figure 5) displays a fall-off in intensity from $2.0 \mu \mathrm{m}$ to $0.5 \mu \mathrm{m}$ due to $\mathrm{Fe}^{2+}$ and $\mathrm{Fe}^{3+}$ absorptions (Hunt, 1982). Resampled to the ASTER bandpasses, the fenite spectrum only retains the amphibole absorption feature centered at near $2.32 \mu \mathrm{m}$ (ASTER band 8). Having only one spectral channel at $2.4 \mu \mathrm{m}$, ASTER cannot resolve the other characteristic amphibole absorption feature centered at near 2.38 $\mu \mathrm{m}$. The ASTER bands 1-5 $(0.56 \mu \mathrm{m}-2.16 \mu \mathrm{m})$ are appropriate to distinguish the rapid fall-off in intensity from $2.0 \mu \mathrm{m}$ to $0.5 \mu \mathrm{m}$ in fenites (Figure 5).

The reflectance spectra of rock samples from the marginal alteration zone generally display ferriciron absorption features in the VNIR wavelength region, due to hematite or limonite (figure 5, MAZ-1, MAZ-2), and sericite $\mathrm{Al}-\mathrm{OH}$ absorptions at $2.20 \mu \mathrm{m}$, $2.35 \mu \mathrm{m}$ and $2.45 \mu \mathrm{m}$ in the SWIR wavelength region. Resampled to the ASTER bandpasses the reflectance spectra of samples from the marginal alteration zone display the ferric-iron absorption feature as a higher reflectance in ASTER band 2 compared to ASTER band 1 (Figure 5). The sericite absorption feature when present is distinguished by ASTER bands 5 to 7 .

The reflectance spectra of the granitic gneisses vary from featureless to displaying $\mathrm{Al}-\mathrm{OH}$ features and/or $\mathrm{Fe}, \mathrm{Mg}-\mathrm{OH}$ features (Figure 5). These features are attributed to muscovite, biotite and chlorite, respectively. These absorption features can be recognized in the ASTER SWIR bands 5-9 as absorption occurring at ASTER bands 6 and 8 (Figure 5). However, the granitic gneisses are extensively covered from lichen, usually of black colour (figure $3 d)$.

A characteristic black lichen reflectance spectrum is shown in figure 6 . The black lichens have near-zero reflectance at visible wavelengths, and reach a maximum reflectance around $1.8 \mu \mathrm{m}$ (Figure 6). The hydroxyl absorption at $1.45 \mu \mathrm{m}$ and the absorption at $1.94 \mu \mathrm{m}$ are caused by water in the lichens (Rees et al., 2004). The characteristic broad absorption features of lichens around $2.1 \mu \mathrm{m}$ and $2.3 \mu \mathrm{m}$ are attributed to cellulose (Ager and Milton, 1987). Resampled to ASTER bandpasses the lichen spectrum retains to a certain extent the absorption features in the short wave infrared ASTER bands 5 to 9 (Figure 6). In addition, the low reflectance of the black lichen in the VNIR bands and the steady rise of the reflectance up to ASTER band $4(1.6 \mu \mathrm{m})$ can be distinguished by the four ASTER bands in this wavelength region.

In the study area, the tundra green vegetation mainly consists of dwarf-shrub (Sieg et al., 2006). A detailed description of the Arctic tundra green vegetation in the study area is beyond the scope of this study. A characteristic reflectance spectrum is shown in figure 6. The ASTER spectral channels can recognize the chlorophyll absorption at about $0.68 \mu \mathrm{m}$, and the rise of reflectance in the VNIR wavelength region (Knipling, 1970). 


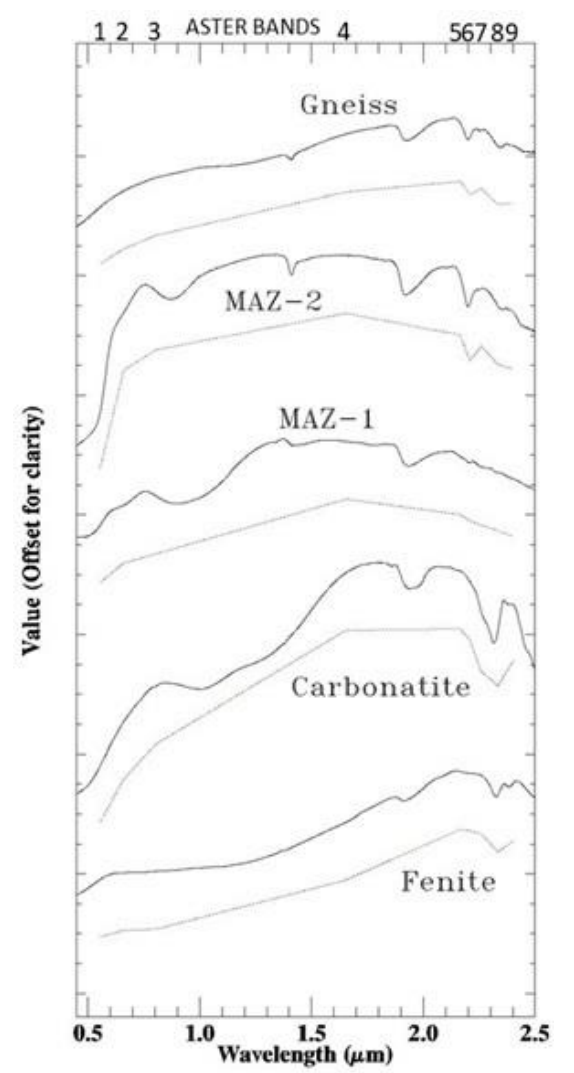

Figure 5 - Pairs of representative reflectance spectra of fenites, carbonatites, marginal alteration zone (MAZ-1, MAZ2) and gneiss from the study area. The upper spectrum (solid line) of each spectral pair is a full resolution ASD spectrum. The lower spectrum of each spectral pair (dotted line) is a spectrum resampled to ASTER bandpasses.

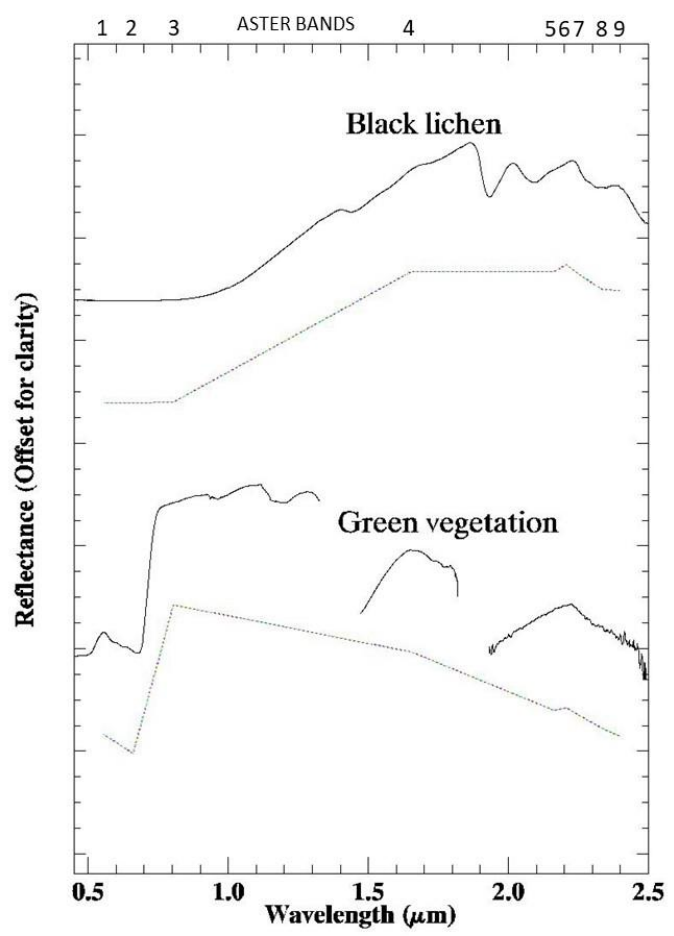

Figure 6 - Pairs of reflectance spectra of green vegetation (arctic dwarf-shrub) and black lichen from Sarfartoq area. The upper spectrum (solid line) of each spectral pair is a full resolution ASD spectrum. The lower spectrum of each spectral pair (dotted line) is a spectrum resampled to ASTER bandpasses. The arctic dwarf-shrub (Green vegetation) spectrum acquired using sun as illumination source. 


\section{ASTER image analysis}

The abundant Arctic tundra vegetation and the mixed spectral response of two or more mineral/lithologic spectral classes within a single pixel (Figure 3) necessitate a form of spectral unmixing in the processing of the Safartoq ASTER data. The ASTER multispectral data were processed using the Adapative Coherence Estimator partial spectral unmixing algorithms (Manolakis et al., 2016). The algorithm require a set of reference spectra for the targeted spectral classes to be detected and mapped in an image. The reference spectra for carbonatite, fenite, limonite, sericite, black lichen/gneiss, green vegetation (Figure 7) were derived from the ASTER image using the "hourglass" hyperspectral data processing scheme (Boardman and Kruse, 2011).

The carbonatite reference spectrum displays the characteristic $\mathrm{CO}_{3}{ }^{2-}$ broad absorption feature centered at ASTER band 8. In the VNIR bands the carbonatite reference spectrum (Figure 7) shows a rapid rise of the reflectance between band 1 and band 2 due to ferric iron. This is characteristic for the carbonatite outcrop at Sarfartoq because of surface weathering of iron-rich dolomite carbonatite. The fenite reference spectrum has an absorption at ASTER band 8 associated with a rapid fall-off of the spectrum in the VNIR (Figure 7) due to ferrous and ferric iron charge transfers in amphibole or biotite. The gneisses are ubiquitously covered by black lichen. The reference spectrum (black lichen/gneiss) was selected aiming to detect black lichen as a proxy to non-altered gneiss. The reference spectrum representing sericite displays the characteristic absorption at ASTER band 6 in relation to ASTER band 7 and band 8. A green vegetation spectrum was also selected (Figure 7).

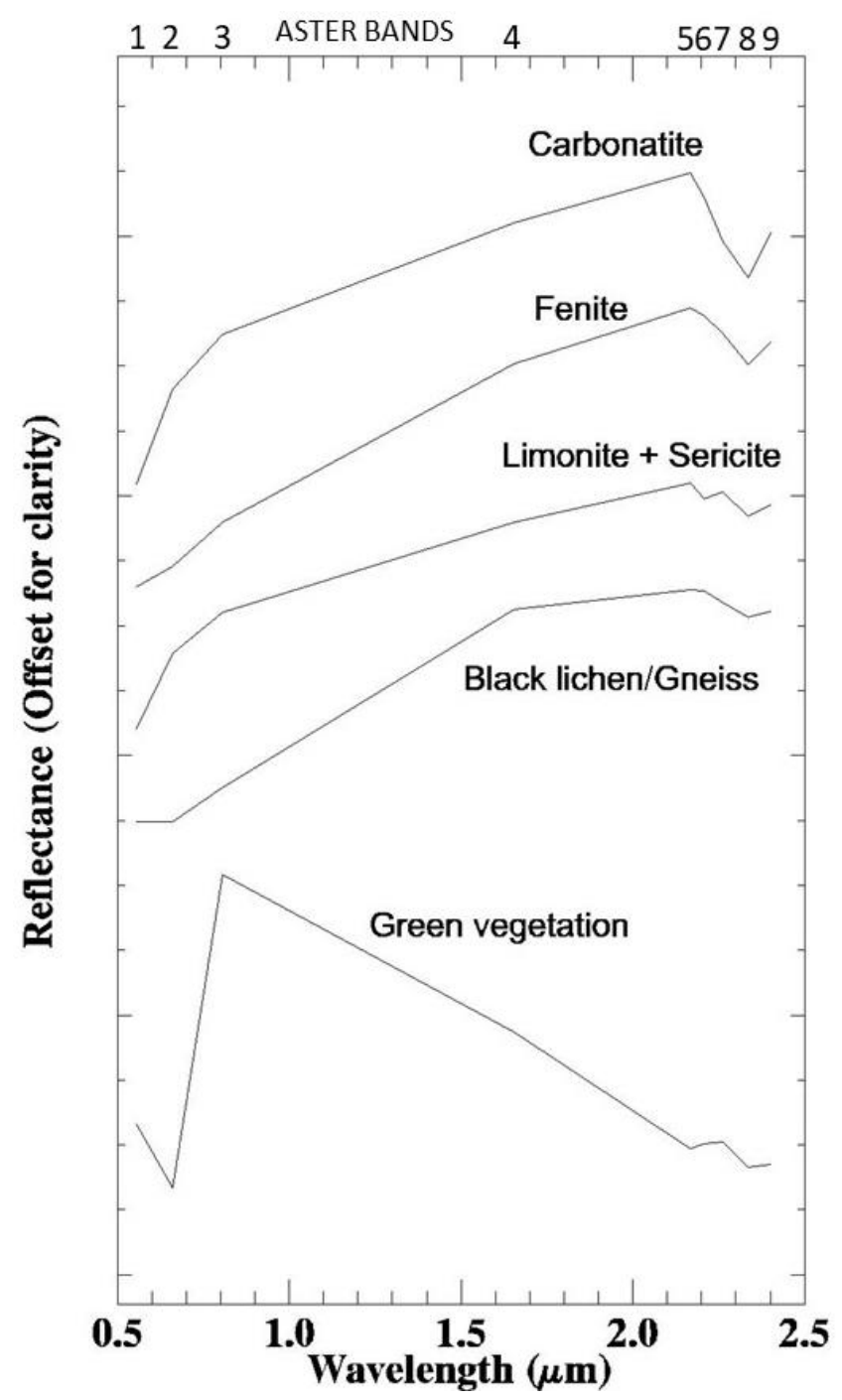

Figure 7 - Reference spectra derived from the ASTER image for carbonatite, fenite, limonite, sericite, black lichen/gneiss, tundra green vegetation. 
The five ASTER SWIR bands $(2.16 \mu \mathrm{m}-2.40$ $\mu \mathrm{m}$, Table 1) were used for the mapping of the carbonatite. The mapping of fenite and lichen/gneiss was based on all the ASTER VNIR-SWIR bands. Four ASTER SWIR bands recording between $(1.6 \mu \mathrm{m}$ $2.27 \mu \mathrm{m}$ ) were used for the mapping of sericite. For the detection of the iron-stained zones (ferric iron absorption) were used the first two ASTER VNIR bands. The result was similar to the ASTER band ratio (band $2 /$ band 1) that is usually employed for the detection of the ferric oxides/hydroxides. The detection of green vegetation was based on the three ASTER VNIR bands recording between $0.55 \mu \mathrm{m}-$ $0.80 \mu \mathrm{m}$.

\section{Results and discussion}

The ACE image analysis results for each of the targeted spectral classes are given in Figure 8. A thematic classification is shown in Figure 9. The main carbonatite outcrop is very well detected (Figures 8a, 9). Minor carbonatite occurrences are found in the Red Canyon shear zone in the southern part of the study area, and in a fault zone in the eastern part of the study area. The carbonatite occurrences in the Red Canyon zone are associated with thorium anomalies, and contain elevated abundances of rare earth elements (Bedini and Rasmussen, 2018). They constitute exploration targets. At Falcon Canyon (Figure 2) drillings guided by the surface outcrop of similar carbonatite occurrences, limonitization, and thorium anomalies led to the discovery of an important rare earth elements deposit (Druecker and Simpson, 2011). The ASTER data processing did not detect carbonatite outcrops at this location. This is related to the small outcrop of carbonatites in this area as compared to the $30 \mathrm{~m}$ spatial resolution of ASTER SWIR bands.

The limonite image shows the main alteration zones and weathered surfaces at Sarfartoq that contain ferric oxides/hydroxides (Figure 8b, 9). The outcropping marginal alteration zone (figure $3 \mathrm{a}$ ) consists of limonitized gneiss (Bedini, 2009). In the same way, the shear zones in the margins of the carbonatite complex are distinguished by their intense limonitization (Secher, 1986), that is detected as a ferric iron absorption in ASTER bands 1 and 2 (Figures 3c, 7, 8b). In other localities, the gneiss rocks within the marginal alteration zone (Figure 2) show limited iron staining. This is related to the glacial activity and to a limited exposure in the surface level (Figure 3e). The carbonatite itself contains ferric oxides/hydroxides due to the surface weathering of iron-rich dolomite carbonatite. The ASTER results show a full picture of the distribution of the major iron-stained zones in the study area.

The fenite lithology is well detected by the ACE algorithm on both sides of the main carbonatite outcrop. In these locations, it can be seen that there is also mixing with carbonatite (i.e. the same pixel contains carbonatite and fenite), which is characteristic for the carbonatite outer core zone (Figure $3 b$ ). The detection of the fenite lithology south of the valley, is not achieved by the analysis of the ASTER $30 \mathrm{~m}$ spatial resolution SWIR data. The difficulty to detect the fenite rocks in these locations is also noted by the analysis of airborne hyperspectral data (Bedini and Rasmussen, 2018). It is to be mentioned the non-uniqueness of the fenite reflectance spectrum consisting of amphibole (or biotite as surface weathering product of amphibole), a factor which explains some relatively good fitting of this spectrum also on areas known to contain non-altered gneiss (Figure 8).

Sericite is detected at the outcropping marginal alteration zone north of the valley (Figure $3 a)$, in the alluvial cover and in the gneiss rocks. According to the reflectance spectroscopy the granite gneiss often contains sericite absorption (Figure 5). The image produced from ACE using the reference spectrum representing lichen/gneiss especially in the northern part mimics the gneiss outcrop pattern. The tundra green vegetation is very well mapped, also showing finer detail due to the use of VNIR bands in the ACE processing. 

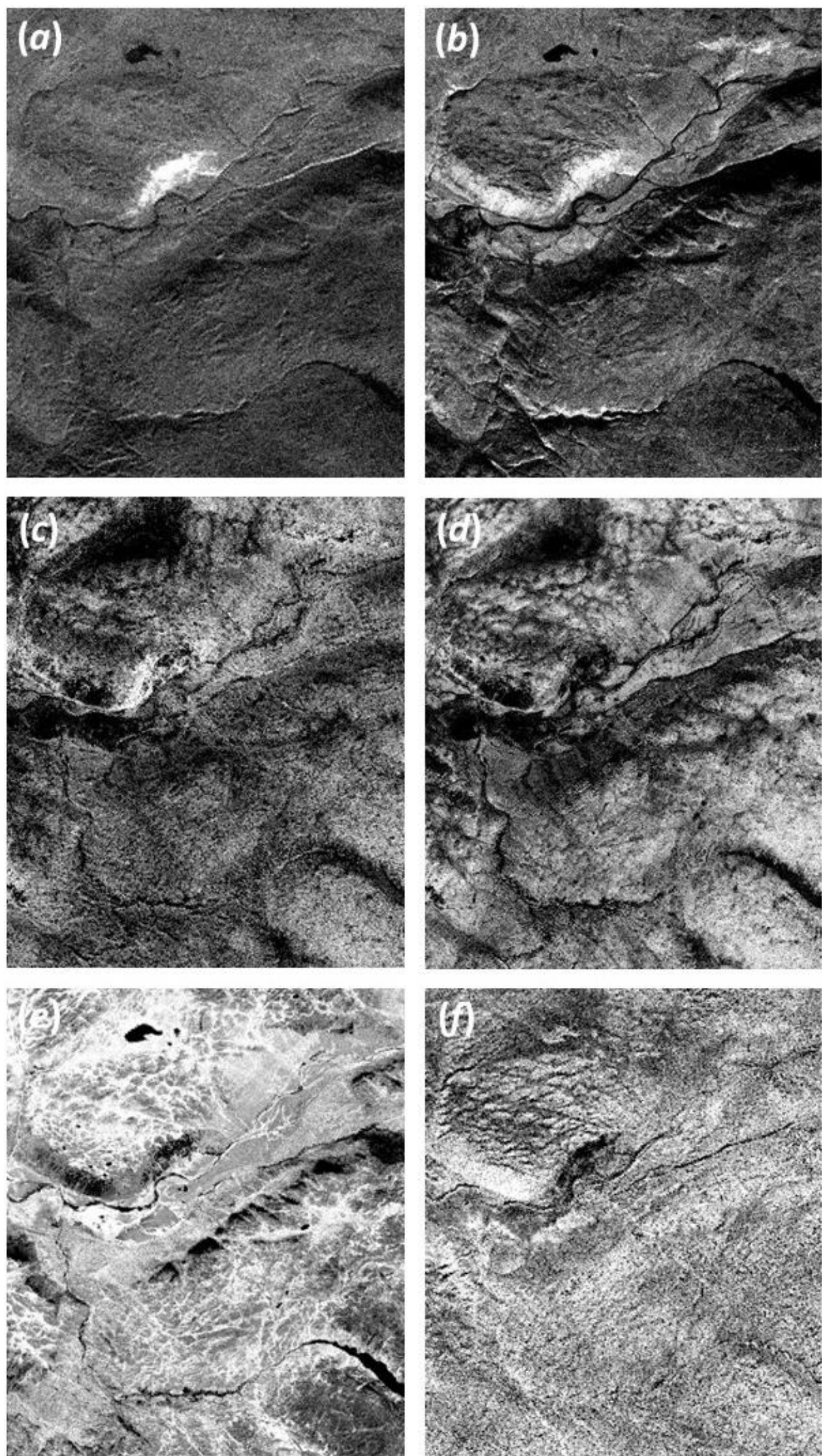

Figure 8 -Results of the partial unmixing processing of the ASTER VNIR-SWIR bands for $(a)$ carbonate, $(b)$ limonite, $(c)$ fenite, $(d)$ lichen/gneiss, $(e)$ tundra green vegetation, and $(f)$ sericite. Brighter levels of grey show higher abundances. The spatial extent of the images is the same as the ASTER infra-red colour composite shown in Figure 4. 


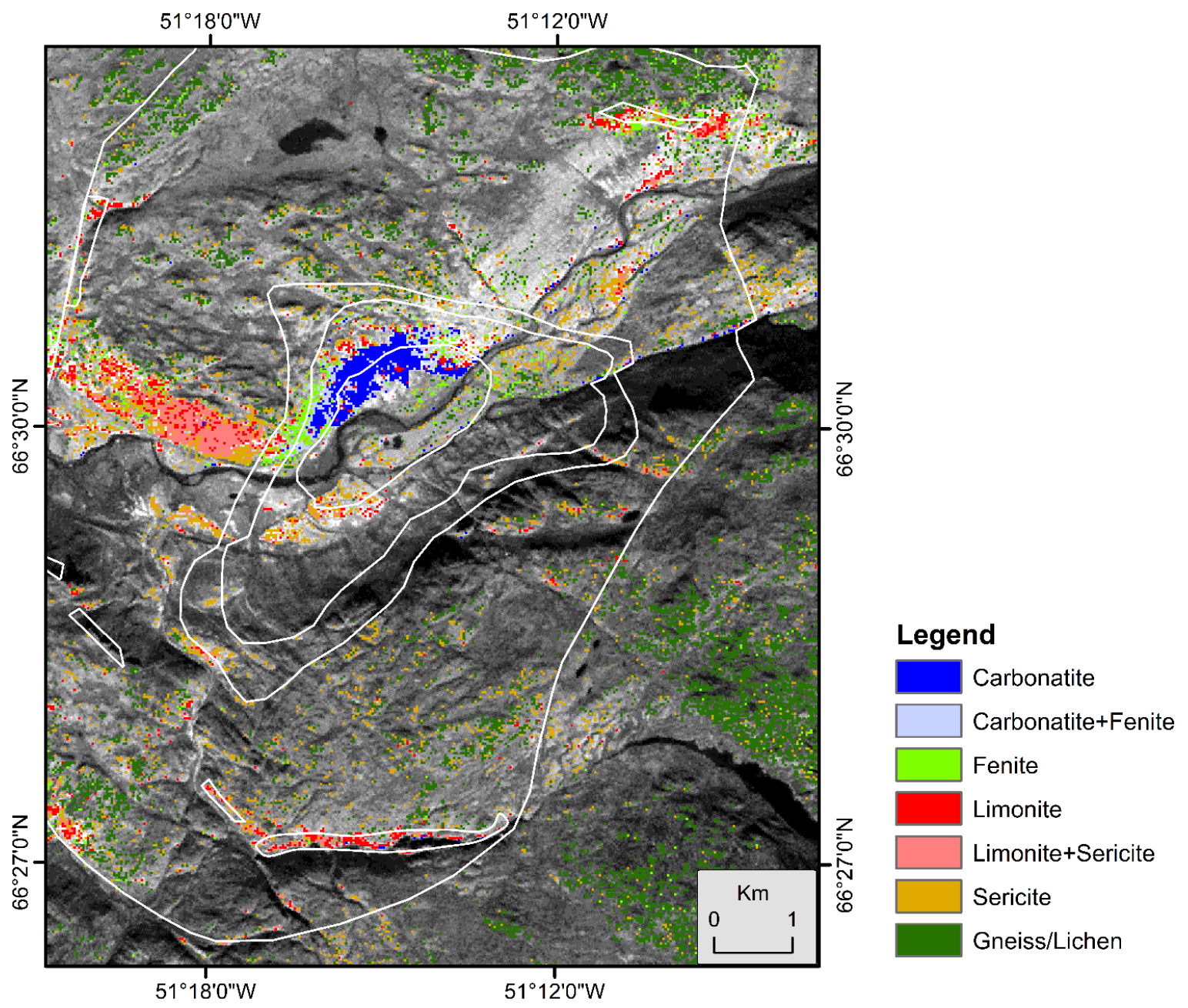

Figure 9 - Thematic classification of the ASTER data produced from the Adaptive Coherence Estimator (ACE) results shown in figure 8 . The boundaries of the schematic geological map of the Sarfartoq carbonatite are also shown on the image for reference. The background is ASTER band 2 image.

\section{Conclusions}

This study used ASTER remote sensing data for mineral and lithologic mapping of the Sarfartoq carbonatite complex in southern West Greenland. The selected study area contains varying lithology and hydrothermal alteration zones, very good rock exposure in cliffs, abundant tundra green vegetation cover and lichens of the rock substrate in the valley plains and plateau level, that are characteristic for the exposed strip of land in southern West Greenland. The ASTER data processing produced good results for the spatial distribution of carbonatite and limonite. These are useful at a reconnaissance stage for a mineral exploration program. The moderate spatial resolution of the ASTER data does not allow for detailed mapping of surface mineralogy and lithology.

The results also show that the remote sensing mapping of gneiss lithology, is hampered in such an Arctic environment by the extensive lichen cover of the gneiss rocks. The use of black lichen as a proxy to map the gneisses is of interest. However, it does not allow to map variations in the composition of the rock substrate. The ASTER data have the advantage of being readily available, cover large areas, and are very useful for reconnaissance mapping of geology and alteration zones in the Arctic regions of southern West Greenland.

\section{References}

Abrams, M., Tsu, H., Hulley, G., Iwao, K., Pieri, D., Cudahy, T., Kargel, J., 2015. The advanced spaceborne thermal emission and reflection radiometer (ASTER) after fifteen years: review of global products. International Journal of Applied Earth Observation and Geoinformation 38, 292301.

Ager, C.M., Milton, N.M., 1987. Spectral reflectance of lichens and their effects on the reflectance of rock substrates. Geophysics 52, 898-906.

Allaart, J.H., 1982. Geological Map of Greenland 1:500 000. Sheet 2, Frederikshåb Isblink - Søndre Strømfjord. Geological Survey of Greenland. Copenhagen, Denmark. 
Bedini, E., Rasmussen, T.M., 2018. Use of airborne hyperspectral and gamma-ray spectroscopy data for mineral exploration at the Sarfartoq carbonatite complex, southern West Greenland. Geosciences Journal 22, 641-651.

Bedini, E., 2017. The use of hyperspectral remote sensing for mineral exploration: a review. Journal of Hyperspectral Remote Sensing 7, 189-211.

Bedini, E., 2012. Mapping alteration minerals at Malmbjerg molybdenum deposit, central East Greenland, by Kohonen self-organizing maps and matched filter analysis of HyMap data. International Journal of Remote Sensing 33, 939961.

Bedini, E., 2011. Mineral mapping in the Kap Simpson complex, central East Greenland using HyMap and ASTER remote sensing data. Advances in Space Research 47, 60-73.

Bedini, E. Tukiainen, T., 2009. Using spectral mixture analysis of hyperspectral remote sensing data to map lithology of the Sarfartoq carbonatite complex, southern West Greenland. Geological Survey of Denmark and Greenland Bulletin 17, 6972.

Bedini, E., 2009. Mapping lithology of the Sarfartoq carbonatite complex, southern West Greenland, using HyMap imaging spectrometer data. Remote Sensing of Environment 113, 1208-1219.

Boardman, J.W., Kruse, F.A., 2011. Analysis of Imaging Spectrometer Data Using n-Dimensional Geometry and a Mixture-Tuned Matched Filtering Approach. IEEE Transactions on Geoscience and Remote Sensing 49 4138-4152.

Clark R.N. 1999. Spectroscopy of rocks and minerals, and principles of spectroscopy, in: Rencz, A.N. (Ed.), Remote Sensing for the Earth Sciences. John Wiley, New York, v. 3, pp. 3-58.

Conradsen, K., Harpøth, O., 1984. Use of Landsat Multispectral Scanner data for detection and reconnaissance mapping of iron oxide staining in mineral exploration, central East Greenland. Economic Geology 79, 1229-1244.

Crosta, A.P., De Souza Filho, C.R., Azevedo, F., Brodie, C., 2003. Targeting key alteration minerals in epithermal deposits in Patagonia, Argentina, using ASTER imagery and principal component analysis. International Journal of Remote Sensing 24, 4233-4240.

Di Tommaso, I., Rubinstein, N., 2007. Hydrothermal alteration mapping using ASTER data in the Infiernillo porphyry deposit, Argentina. Ore Geology Reviews 32, 275-290.

Druecker, M., Simpson, R.G., 2011. Advanced technical report on the Sarfartoq project West Greenland. Prepared for Hudson Resources Inc.

Gaffey, S.J., 1986. Spectral reflectance of-carbonate minerals in the visible and near infrared $(0.35-2.55$ microns): calcite, aragonite, and dolomite. American Mineralogist 71, 151-162.

Guha, A., Singh, V.K., Parveen, R., Kumar, K.V., Jeyaseelan, A.T., Rao, E.D., 2013. Analysis of ASTER data for mapping bauxite rich pockets within high altitude lateritic bauxite, Jharkhand, India. International Journal of Applied Earth Observation and Geoinformation 21, 184-194.

Hunt G.R., 1982. Spectroscopic properties of rocks and minerals. In Handbook of Physical Properties of Rocks ed. Carmichael, R.S., CRC Press, pp. 295-385.

Jones, A.P., Genge, M., Carmody, L., 2013. Carbonate melts and carbonatites. Reviews in Mineralogy \& Geochemistry 75, 289-322.

Knipling, E.B., 1970. Physical and physiological basis for the reflectance of visible and near-infrared radiation from vegetation. Remote Sensing of Environment 1, 155-159.

Kumar, C., Shetty, A., Raval, S., Sharma, R., Ray, P.C., 2015. Lithological Discrimination and Mapping using ASTER SWIR Data in the Udaipur area of Rajasthan, India. Procedia Earth and Planetary Science 11, 180-188.

Manolakis, D., Lockwood, R., Cooley, T., 2016. Hyperspectral Imaging Remote Sensing: physics, sensors, and algorithms. Cambridge University Press, Cambridge.

Mars, J.C., Rowan, L.C. 2011., ASTER spectral analysis and lithologic mapping of the Khanneshin carbonatite volcano, Afghanistan. Geosphere 7, 276-289.

Ninomiya, Y., Fu, B., 2016. Regional lithological mapping using ASTER-TIR data: case study for the Tibetan Plateau and the surrounding area. Geosciences 6, 39.

Obata, K., Tsuchida, S., Iwao, K., 2015. Inter-Band Radiometric Comparison and Calibration of ASTER Visible and Near-Infrared Bands. Remote Sensing 7, 15140-15160.

Pour, A.B., Hashim, M., Park, Y., Hong, J.K., 2017. Mapping alteration mineral zones and lithological units in Antarctic regions using spectral bands of ASTER remote sensing data. Geocarto International 1-26.

Pour, A.B., Hashim, M., 2012. Identifying areas of high economic-potential copper mineralization using ASTER data in the Urumieh-Dokhtar Volcanic Belt, Iran. Advances in Space Research 49, 753-769.

Rajendran, S., Nasir, S., 2015. Mapping of high pressure metamorphics in the As Sifah region, NE Oman using ASTER data. Advances in Space Research 55, 1134-1157.

Rasmussen, T.M., Thorning, L., Riisager, P., Tukiainen, T., 2013. Airborne geophysical data 
from Greenland. Geology and Ore, Geological Survey of Denmark and Greenland 22, 12.

Rees, W.G., Tutubalina, O.V., Golubeva, E.I., 2004. Reflectance spectra of subarctic lichens between 400 and $2400 \mathrm{~nm}$. Remote Sensing of Environment 90, 281-292.

Rivard, B., Arvidson, R.E., 1992. Utility of imaging spectrometry for lithologic mapping in Greenland. Photogrammetric Engineering \& Remote Sensing 58, 945-949.

Rockwell, B.W., Hof stra, A.H., 2008. Identification of quartz and carbonate minerals across northern Nevada using ASTER thermal infrared emissivity data-Implications for geologic mapping and mineral resource investigations in well-studied and frontier areas. Geosphere 4, 218-246.

Rowan, L.C., Mars, J.C., Simpson, C.J., 2005. Lithologic mapping of the Mordor, NT, Australia ultramafic complex by using the Advanced Spaceborne Thermal Emission and Reflection Radiometer (ASTER). Remote sensing of Environment 99, 105-126.

Rowan, L.C., Mars, J.C., 2003. Lithologic mapping in the Mountain Pass, California area using advanced spaceborne thermal emission and reflection radiometer (ASTER) data. Remote sensing of Environment 84, 350-366.

Secher, K., Heaman, L.M., Nielsen, T.F.D., Jensen, S. M., Schjøth, F., Creaser, R.A., 2009. Timing of kimberlite, carbonatite, and ultramafic lamprophyre emplacement in the alkaline province located 64-67 $\mathrm{N}$ in southern West Greenland. Lithos 112, 400-406.

Secher, K., 1986. Exploration of the Sarfartoq carbonatite complex southern West Greenland. Rapport Grønlands Geologiske Undersøgelse 128, 89-101.

Secher, K., Larsen, L.M., 1980. Geology and mineralogy of Sarfartoq carbonatite complex, southern West Greenland. Lithos 13, 199-212.

Sieg, B., Drees, B., Daniëls, F.J., 2006. Vegetation and altitudinal zonation in continental West Greenland. Meddelelser om Grønland Bioscience 57, 93.

Son, Y.S., Kang, M.K., Yoon, W.J., 2014. Lithological and mineralogical survey of the Oyu
Tolgoi region, Southeastern Gobi, Mongolia using ASTER reflectance and emissivity data. International Journal of Applied Earth Observation and Geoinformation 26, 205-216.

Sørensen, E.V., Guarnieri, P., 2018. Remote geological mapping using 3D photogrammetry: an example from Karrat, West Greenland. Geological Survey of Denmark and Greenland Bulletin 41, 6366.

Tangestani, M.H., Mazhari, N., Agar, B., Moore, F., 2008. Evaluating Advanced Spaceborne Thermal Emission and Reflection Radiometer (ASTER) data for alteration zone enhancement in a semi-arid area, northern Shahr-e-Babak, SE Iran. International Journal of Remote Sensing 29, 2833 2850.

Tayebi, M.H., Tangestani, M.H., Vincent, R.K., Neal, D., 2014. Spectral properties and ASTER-based alteration mapping of Masahim volcano facies, SE Iran. Journal of Volcanology and Geothermal Research 287, 40-50.

Tukiainen, T., Thomassen, B., 2010. Application of airborne hyperspectral data to mineral exploration in North-East Greenland. Geological Survey of Denmark and Greenland Bulletin 20, 71-74.

Tukiainen, T. Thorning, L., 2005, Detection of kimberlitic rocks in West Greenland using airborne hyperspectral data: the Hyper-Green 2002 project. Geological Survey of Denmark and Greenland Bulletin 7, 69-72.

Winter J.D., 2001. An introduction to Igneous and Matamorphic Petrology. Prentice-Hall Inc, New Jersey.

Yamaguchi, Y., Kahle, A., Tsu, H., Kawakami, T., Pniel, M., 1998. Overview of Advanced Spaceborne Thermal Emission and Reflection Radiometer (ASTER). IEEE Transactions in Geoscience and Remote Sensing 36, 1062-1071.

Yamaguchi, Y., Fujisada, H., Kahle, A.B., Tsu, H., Kato, M., Watanabe, H., Sato, I., Kudoh, M., 2001. ASTER instrument performance, operation status, and application to Earth sciences, in: Geoscience and Remote Sensing Symposium. IGARSS'01. IEEE 2001 International 3, 1215-1216. 